\title{
How a Fundamentally Different and New Glacial History Paradigm Explains North America Glaciated Prairie Region Erosional Escarpments and Drainage Patterns
}

\author{
Eric Clausen ${ }^{1}$ \\ ${ }^{1}$ Independent Researcher, Jenkintown, PA 19046, United States \\ Correspondence: Eric Clausen, Independent Researcher, Jenkintown, PA 19046, United States. \\ E-mail: eric2clausen@gmail.com
}

Received: March 6, 2019

Accepted: April 3, 2019

Online Published: July 17, 2019

doi:10.5539/esr.v8n2p23

URL: https://doi.org/10.5539/esr.v8n2p23

\begin{abstract}
Scientific paradigms are frameworks of ideas governing how a discipline conducts its research. Paradigms by themselves are neither correct nor incorrect, but are judged on their ability to explain evidence and to open up research opportunities. The commonly accepted glacial history paradigm requires North American glaciated prairie region erosional landform features, such as erosional escarpments and abandoned valleys associated with the north-oriented Bell River drainage system, to be pre-glacial in origin. While considerable literature is based on such interpretations those escarpments and abandoned valleys are formed in easily eroded bedrock and should not have survived continental ice sheet erosion. In addition to defying common sense logic the pre-glacial origin of those erosional escarpments and abandoned valleys is not well understood. A new paradigm requiring at least one continental ice sheet to have occupied a deep North American "hole" (formed by deep ice sheet erosion and ice sheet caused crustal warping) offers geomorphologists an opportunity to explain the erosional escarpments as remnants of canyon walls originally formed when supra-glacial rivers sliced ice-walled and bedrock-floored canyons into a decaying continental ice sheet's surface and the abandoned north-oriented Bell River drainage system valleys to have been eroded as the ice-walled and bedrock-floored canyon network captured and diverted massive melt water floods onto and then across the decaying ice sheet's floor and then in northeast and north directions between detached and semi-detached ice sheet remnants. The diversion of immense melt water floods from the Gulf of Mexico to the North Atlantic Ocean triggered climatic change that ended the first ice sheet's melting. Water in the newly formed north-oriented drainage systems then froze between the detached and semi-detached (and greatly thinned) ice sheet remnants to create a second and much thinner ice sheet and to complete creation of the glaciated prairie region glacial features seen today.
\end{abstract}

Keywords: Bell River drainage system, Manitoba Escarpment, Missouri Coteau, Missouri Escarpment, Pembina Escarpment, Prairie Coteau, Turtle Mountains

\section{Introduction}

Prominent erosional escarpments found throughout the North America's glaciated prairie region include the Missouri Escarpment (ME on figure 1), the Pembina Escarpment (PE) and its northward extension the Manitoba Escarpment, and escarpments surrounding the Prairie Coteau, Turtle Mountains, Moose Mountains, Last Mountain, and other Canadian uplands further to the north. While these escarpments represent some of the region's most obvious physiographic features, they are usually considered pre-glacial in origin and those origins are poorly explained. Associated with the pre-glacial escarpment hypothesis is the interpretation that north oriented rivers such as the Yellowstone (Y in figure 1), Little Missouri (LM), Cheyenne (C), and Red (R) Rivers originated as components of a major north-oriented pre-glacial drainage network, known in the geologic literature as the Bell River drainage system (e.g. Jackson, 2018 and Sears, 2013). Segments of other rivers also seen in figure 1, including the Assiniboine (A), Belle Fourche (B), James (J), Qu'Appelle (Q), Sheyenne (SH), Souris (S), and South Saskatchewan (SS), are also interpreted to flow in valleys that once served as pre-glacial north-oriented Bell River drainage system components. Yet the pre-glacial origin interpretation does not explain how pre-glacial landforms carved in easily eroded bedrock survived multiple glaciations or how the pre-glacial Bell River drainage system and the associated erosional escarpments originated. 


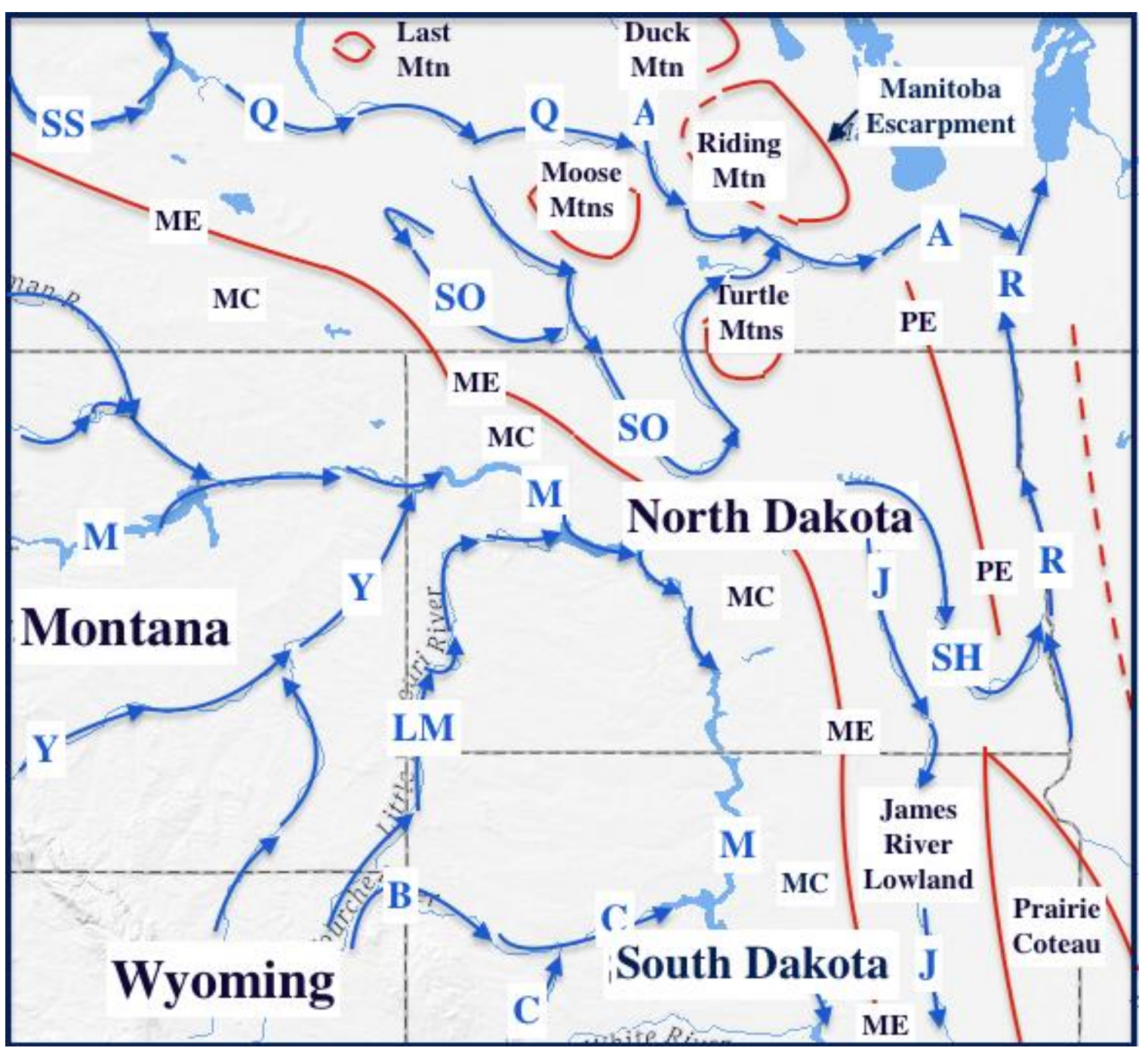

Figure 1. Modified map from the United Stated States Geological Survey (USGS) National Map website showing this paper's study region. Rivers are identified by blue arrows and letters and the escarpments by red lines and black letters as indicated in the text and the black letters MC identify the Missouri Coteau location. The Moose Mountains are in southeast Saskatchewan and the Turtle Mountains north half and Riding Mountain are in southwest Manitoba

The interpretation that now abandoned north-oriented Bell River drainage system valleys and the erosional escarpments originated prior to continental glaciation helps to define the commonly accepted regional glacial history paradigm. Publications describing elements of that paradigm include Bluemle (1972 and 1991), Leckie (2006), and Cummings et al, (2012). Paradigms according to Kuhn (1970) are frameworks of ideas governing how a scientific research community conducts its research and by themselves are neither correct nor incorrect. Instead paradigms are judged on their ability to explain evidence and to open up productive new research opportunities. While maybe successful in opening up research opportunities for investigators studying the stratigraphy of glacially deposited sediments and paleontological evidence contained in those sediments (at least the scientific literature shows a fairly continuous stream of research papers related to those aspects of the regional glacial history), the same has not been true for investigators interested the origin of the region's large-scale erosional landforms, such as the escarpments and drainage systems. For geomorphologists the commonly accepted regional glacial history paradigm makes satisfactory explanations of large-scale erosional landforms such as the escarpments and drainage systems difficult, if not impossible, and as a result many glaciated prairie region landforms origins are still poorly understood.

Bluemle (1991), who saw the Missouri Escarpment as a pre-glacial erosional feature, in a typical large-scale landform origin description suggests, "The origins of most of the escarpments found in North Dakota are probably tied to events before the state was glaciated, although glacial processes enhanced and steepened the 
features." Bluemle goes on to say, "Before they were glaciated, the Turtle Mountains and Prairie Coteau were erosional outliers - probably low mesas - of Cretaceous and Tertiary sandstone formations that stood above the surrounding plain." Leckie (2006) addresses why such erosional outliers formed by saying "The early Tertiary of Western Canada and northern United States was marked by change from compressional to extensional tectonics. The result was regional uplift and magmatic events. The uplift resulted in a major unconformity and deposition of extensive sheets of gravel and sand, of which only isolated remnants remain. These units are the Eocene to Miocene Cypress Hills Formation, the Miocene Wood Mountain Formation, Miocene Flaxville Formation and pre-glacial Souris River gravels... The sediment was deposited several hundred kilometers downstream of their source areas.... The modern prairie landscape of western Canada began to evolve with the deposition of these gravels during the Eocene with creation of a basin-wide unconformity followed by deposition of an extensive braidplain system that was subsequently uplifted, incised, and molded to its present form." While rarely challenged such vague interpretations have not led to a good understanding of the large-scale landform origins.

The commonly accepted regional glacial history paradigm's inability to open up new geomorphology research opportunities is perhaps best illustrated by what happened or did not happen during the $20^{\text {th }}$ century as United Stated States Geologic Survey (USGS) detailed topographic map coverage expanded. While topographic maps for some United States regions had been available since the late $19^{\text {th }}$ century detailed topographic map coverage for many United States regions, including some glaciated prairie region areas, did not become available until the mid and even the late $20^{\text {th }}$ century. As new detailed topographic map coverage became available vast quantities of new and previously unstudied landform data became available and should have opened up numerous new geomorphology research opportunities. Instead of opening up new research opportunities topographic map interpretation (which had been one of geomorphology's most useful research tools) almost completely disappeared as a commonly taught university geology and/or geography course and research papers describing geomorphological studies of the type included in Thornbury (1965) and Fenneman (1931), in which topographic map interpretation plays an important role, became progressively less common. The newly available detailed topographic map coverage, which should have been a geomorphology research gold mine, for unexplained reasons was being ignored.

This author's research related to the Missouri Escarpment origin began in 1979 while serving as a Minot State University faculty member. Minot, North Dakota (the university's home) is located in the glaciated prairie region along the Souris River near the Missouri Escarpment base (see figure 2). Literature related to the Missouri Escarpment origin and available at that time included a USGS Professional Paper (Lemke, 1960), which suggested the Missouri Escarpment might be a pre-glacial fault scarp and which also proposed the Missouri Escarpment front had channeled a long narrow ice lobe along it in a southeast direction. Lemke further regarded the Missouri Coteau (a zone of thick glacially deposited debris between the Missouri Escarpment crest and the Missouri River and labelled MC on figure 1) to be a terminal moraine, which in some earlier literature had been referred to as the Max moraine (Townsend and Jenke, 1951). Evidence cited by Lemke for faulting along and near the Missouri Escarpment and along and near the Turtle Mountains southwest escarpment are small localized regions of tilted bedrock sometimes standing at sharp angles to the prevailing nearly horizontal and easily eroded claystone bedrock (which also includes discontinuous sandstone and lignite units). The tilted bedrock units are typically several hundreds of meters in length and by 1979 other investigators had begun to interpret them as ice thrust features (i.e. blocks of ice-moved frozen bedrock).

Lemke's interpretations were later summarized (in Lemke et al, 1965) by the statement that the Missouri Escarpment "acted as a buttress to advancing ice sheets and played an important role in determining directions of ice advances and the positions of end moraines". Also available at that time were several papers included in a publication (Clayton, L. and Freers, T.F., 1967) that suggested the Missouri Coteau (between the Missouri Escarpment and the Missouri River) was a region of thick glacially transported debris left after an underlying stagnant ice mass had slowly melted. Lemke and other workers described glacial deposits found on the Missouri Escarpment slope or in lowland regions between the Missouri Escarpment and Turtle Mountains to be quite different. Streams flowing down the northeast-facing Missouri Escarpment slope and southwest-facing Turtle Mountains escarpment slope have cut through relatively thin glacial tills and into the easily eroded underlying bedrock consisting of claystone that disintegrates when placed in water (and that contains discontinuous sandstone and lignite units). Likewise, relatively thin glacial tills cover large areas of the lowlands between the Missouri Escarpment and the Turtle Mountains. Based on the then available literature and field observations this author attempted several thought experiments to explain the larger-scale physiographic features.

One early thought experiment used a southeastward advancing ice lobe as an erosion agent to explain the northeast-facing Missouri Escarpment and southwest-facing Turtle Mountains escarpment with the thick glacial 
deposits on the Missouri Coteau upland and on the Turtle Mountains upland being lateral moraines (although only a lateral moraine remnant was present on the Turtle Mountains), however those explanations did not explain all of the evidence and conflicted with earlier North Dakota drainage history interpretations (e.g. Bluemle, 1972). Those drainage history interpretations describe abandoned valleys, now partially buried in glacial debris, to be pre-glacial Bell River system components. Some abandoned valleys cross the Missouri Coteau and Missouri Escarpment and can be traced across lowlands to the north and northeast. While the thought experiment did not satisfactorily explain those abandoned valleys, it did point out the absurdity of the pre-glacial Bell River drainage system hypothesis, which implies valleys eroded in easily eroded bedrock withstood multiple continental ice sheet advances. The thought experiment introduced White's (1972) deep erosion by continental ice sheets hypothesis. Unfortunately, severe criticism (e.g. Sugden 1976) led the geology research community to overwhelming reject White's deep continental ice sheet erosion ideas.

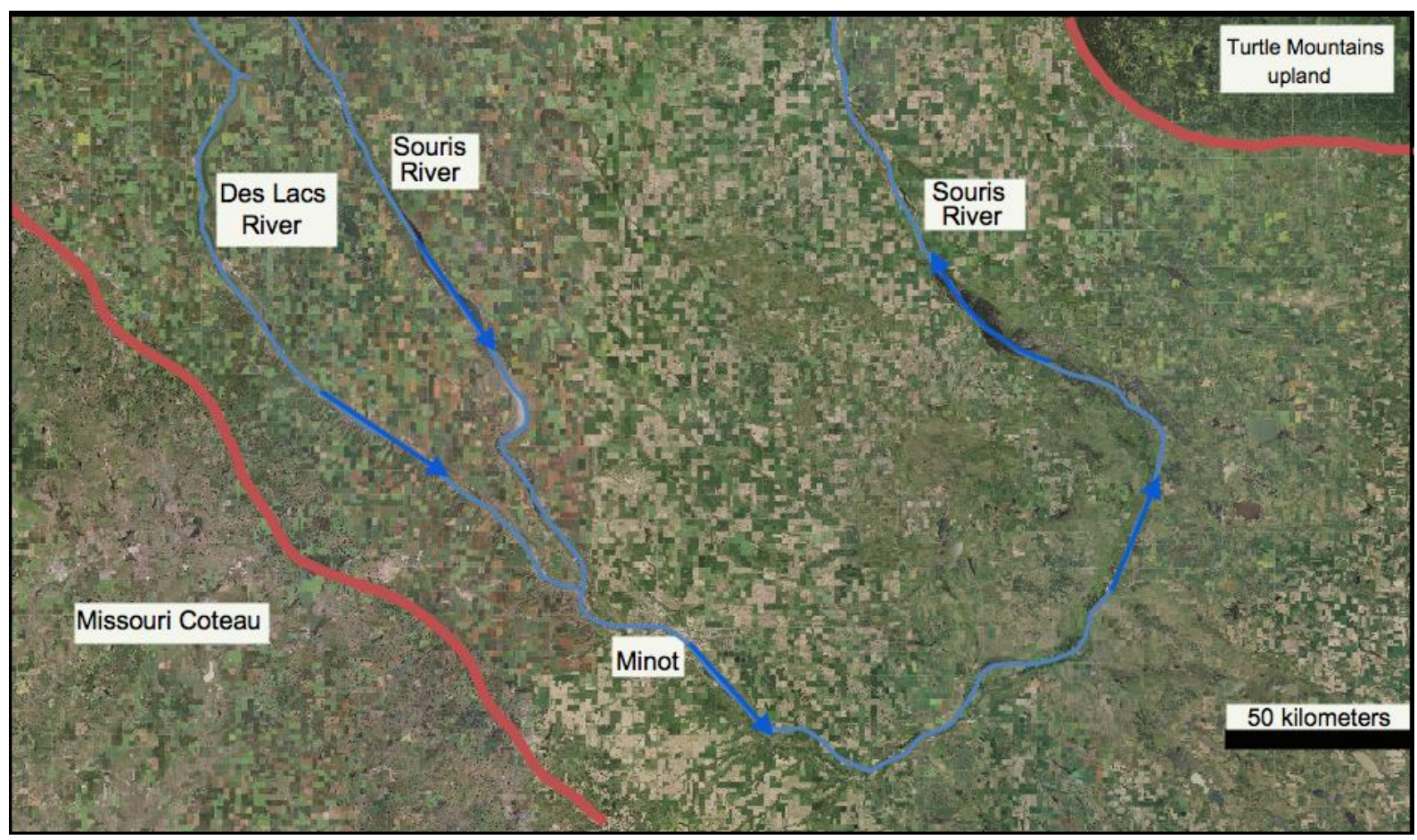

Figure 2. Satellite imagery from USGS National Map website showing the northcentral North Dakota Souris River loop located between the Missouri Escarpment and the escarpment-bounded Turtle Mountains. The Des Lacs River and Souris River southeast-oriented segment through Minot flow along the Missouri Escarpment base. Red lines mark escarpment crests

Recently Clausen in several papers (e.g. 2017a, 2018a, and 2018b), using evidence primarily obtained from regions to the south and west of glaciated areas (e.g. to the south and west of the Missouri River), has revived the deep erosion by continental ice sheets concept (although in a form different from what White suggested) by suggesting that at least one large North American continental ice sheet created (by ice sheet caused deep erosion and by ice sheet caused crustal warping) and occupied a deep "hole" and that the glaciated prairie region erosional escarpments and north-oriented Bell River drainage system valleys originated during that continental ice sheet's decay. This paper demonstrates how a new and fundamentally different glacial history paradigm explains glaciated prairie region glacial features, erosional escarpments, north-oriented Belle River drainage system valleys (and glacial deposits now partially filling some of those abandoned valley segments), and how the modern-day Missouri River route originated. The new glacial history paradigm is fundamentally different from the commonly accepted regional glacial history paradigm and must be judged, not by how its interpretations agree with commonly published glacial history paradigm interpretations, but by its ability to explain previously unexplained and poorly explained evidence and to open up new research opportunities.

\section{Research Method}

Development of the new glacial history paradigm used western United States and western Canada detailed 
topographic maps and tested multiple alternate hypotheses over a period of more than 20 years. The decision to use detailed topographic maps was made because those maps provided an opportunity to work with vast quantities of previously unstudied geomorphological data to determine where ice-marginal water had flowed when North American continental ice sheet margins reached their maximum extent. Most commonly accepted interpretations consider the modern-day Missouri River route (except the north-oriented central Montana Missouri River headwaters, which are west of Figure 1), to have originated when a continental ice sheet blocked pre-glacial north- and northeast-oriented drainage routes such as north-oriented Missouri River headwaters (west of figure 1) and the Yellowstone, Little Missouri, and Cheyenne Rivers (seen in figure 1), however glacial erratic boulders are found tens of kilometers to the west and south of the North and South Dakota Missouri River. Those erratic boulders suggest a continental ice sheet once extended several tens of kilometers to the west and south of the Missouri River and the assumption was made that evidence should exist along present-day drainage divides to the west and south of Missouri River showing where water from the blocked pre-glacial north-oriented drainage routes and from that melting continental ice sheet had once flowed.

The ensuing investigation began in the early 1980s by first studying geologic maps and the published literature to note previously recognized ice-marginal drainage routes to the west and south of the present-day Missouri River. For example, the Geologic Map of North Dakota (Clayton, 1980) shows an abandoned river channel to the west and south of the Missouri River, but not to the west and south of the mapped glacial erratic margin. Further, when observed in the field that abandoned river channel, while significant in size, was not judged large enough to have carried the volume of ice-marginal water that on a warm summer day should have been flowing along a continental ice sheet's boundary. Similar conclusions were reached for other previously suggested ice-marginal channel locations to the south and west of the Missouri River. Next detailed topographic maps showing drainage divides between north- and northeast-oriented Missouri River tributaries to the west and south of the mapped glacial erratic margin were studied. The maps showed numerous closely-spaced notches along north-to-south oriented drainage divides linking what are today southeast-oriented tributary stream valleys with northwest-oriented tributary stream valleys suggesting that multiple closely spaced southeast-oriented channels, such as might be found in a large-scale anastomosing channel complex, had crossed the entire ice-marginal region prior to headward erosion of the deeper north- and northeast-oriented Missouri River tributary valleys (see Clausen, 2017a).

Finding evidence for large-scale flood formed southeast-oriented anastomosing channel complexes to the west and south of the glacial erratic southwest limit was not unexpected, but two unexpected observations did emerge. First, valleys of what are today north- and northeast-oriented Missouri River tributaries (components of the "pre-glacial" Bell River drainage system) could only be explained if they had eroded headward from the continental ice sheet and then across southeast-oriented ice-marginal floods, which meant the Bell River drainage system was not pre-glacial in origin as most published interpretations claim, but which also meant the continental ice sheet from which the valleys had eroded melted in ways yet to be described. The second unexpected observation was the notches crossing drainage divides continued without interruption from the glacial erratic margin in an upstream direction along drainage divides between north- and northeast-oriented Missouri River tributaries into high Rocky Mountain regions and the most intriguing evidence was in the form of deep mountain passes located high in the Rocky Mountains (some examples are described in Clausen, 2017b).

Considerable time was spent trying to figure out where water that eroded the high Rocky Mountain passes had come from (and then had flowed) and eventually large mosaics of detailed topographic maps were used to show how large southeast-oriented ice-marginal floods had once crossed what is today the entire Missouri River drainage basin and how those massive floods had been systematically captured as deep valleys eroded headward into the Rocky Mountain region. But before that conclusion could be reached the possibility of large ice-dammed lakes was considered and rejected because some flood waters could be traced to high Montana mountain passes that cross what is today the North American east-west continental divide. In fact the map evidence suggested immense south- and southeast-oriented floods once flowed in a south direction from the Canadian Rocky Mountains along and across North America's east-west continental divide and that the Montana, Wyoming, and Colorado continental divide had formed when headward erosion of deep valleys from the continental ice sheet's location (to the north and northeast), the Gulf of Mexico (to the east), and the Pacific Ocean (to the west) had in an identifiable sequence captured the large south- and southeast-oriented floods.

The only interpretation explaining the detailed topographic map evidence was that at least one North American continental ice sheet had created and occupied a deep "hole" in the North American continent and that the Rocky Mountains had risen as huge melt water floods had flowed across them. In other words, the deep "hole" could not be explained by just deep continental ice sheet erosion (as White had proposed), but required ice sheet 
triggered crustal warping and that conclusion is discussed in Clausen (2018b). However, if at least one North American ice sheet did deeply erode the underlying bedrock then the glaciated prairie region erosional escarpments and abandoned Bell River drainage system valleys to the north and east of the present-day Missouri River drainage basin cannot be pre-glacial landforms. Restudy of published regional glacial and geologic maps such as the "Preliminary Glacial Map of North Dakota" (Colton et al, 1963) and the subsequent "Geologic Map of North Dakota" (Clayton, 1980) along with newer publications identifying and describing ice thrust features (e.g. Bluemle and Clayton, 1984) and exceptionally long, narrow drumlins (e.g. Bluemle, 1993), which are found just to the east of the Missouri Escarpment and south of figure 2, suggested the erosional escarpments and other large-scale features told a fundamentally different regional glacial history than the commonly accepted glacial history describes.

Perhaps the most significant observations of large-scale glacial features obtained from prairie region field work and published glacial maps and literature is the Missouri Coteau stagnation moraines to the west and southwest of the Missouri Escarpment are similar to stagnation moraines found capping the Turtle and Moose Mountains and Last Mountain and the Prairie Coteau upland. Further similar stagnation moraines also cap Riding Mountain, Duck Mountain, and other Canadian uplands. While stagnation moraines cover the Missouri Coteau and cap the prairie region escarpment-surrounded uplands much thinner glacial deposits cover the escarpment slopes and most of the intervening lowland areas where the ice stagnation moraines are rare or limited to identifiable ice lobe end moraine areas. Instead the intervening lowlands, especially between the Missouri Escarpment and the Turtle Mountains, are marked by ice-thrust features and narrow linear drumlin features suggesting (as Lemke had proposed) a mobile wet-based ice lobe had flowed in a southeast direction along the Missouri Escarpment front. In other words, the large-scale glacial features suggest the presence of two fundamentally different ice sheet types. The Missouri Coteau and the escarpment-surrounded uplands show evidence of having been covered by slowly melting debris-covered stagnant ice masses while much cleaner mobile and wet-based ice lobes filled the intervening lowlands.

\section{Results}

\subsection{Subdividing a Continental Ice Sheet Into Detached and Semi-Detached Ice Sheet Masses}

Some investigators explain the two different prairie region glaciation types by considering Missouri Coteau stagnation moraines to be a major terminal moraine (e.g. Townsend and Jenke, 1951). Such an interpretation is consistent with the interpretation that the North and South Dakota Missouri River (which in North Dakota roughly follows the Missouri Coteau southwest margin and in South Dakota the Missouri Coteau west boundary) originated when a continental ice sheet blocked north-oriented pre-glacial drainage routes. While perhaps explaining the Missouri Coteau stagnation moraines this interpretation does not explain stagnation moraines capping the Prairie Coteau, Turtle Mountains, Moose Mountains, Last Mountain, Riding Mountain, Duck Mountain, and other uplands, nor does it explain evidence for southeast-oriented and mobile wet-based ice lobes in the lowland regions between the Missouri Escarpment and Turtle Mountains. Further, such an interpretation does not explain why in North and South Dakota coarse-grained glacial erratic material, including large boulders, is found for tens of kilometers to the south and west of the Missouri River. The presence of glacial erratic material to the south and west of the Missouri River has sometimes been interpreted to have been deposited by an earlier continental ice sheet, although Flint (1955) used boulder weathering to suggest a complicated hypothesis to explain how one ice sheet could deposit erratic boulders on both sides of a pre-ice sheet Missouri River valley. Flint's complicated hypothesis failed to convince other workers and did not satisfactorily explain most evidence.

The differences between the stagnation moraine areas and mobile wet-based ice lobe areas can also be explained by a fundamentally new and different two-ice sheet hypothesis with a thin ice sheet developing when water accumulated and froze in ice-walled and bedrock-floored lowlands located between decaying first ice sheet remnants. The stagnant moraine covered areas are where the first ice sheet remnants were located and lowlands between the erosional escarpments are where water accumulated and froze (from the top down) to form mobile wet-based ice lobes. Such an interpretation supports conclusions reached while conducting the Missouri River drainage basin topographic map investigation (that at least one continental ice sheet had created and occupied a deep "hole") and explains most, if not all of the glaciated plains region large-scale glacial features. This new two-ice sheet hypothesis begins with a large North American ice sheet (perhaps equivalent in size to the one Paterson described in 1972) that did deeply erode the underlying bedrock and that also caused significant crustal warping of surrounding continental areas so as to create and occupy a deep "hole". In time that large continental ice sheet melted, but unlike most commonly published North American deglaciation reconstructions (e.g. Dyke, 2004) that large ice sheet did not decay from its margins towards its center, but instead decayed as large 
supraglacial rivers sliced ice-walled and (eventually) bedrock-floored canyons into the ice sheet's surface as huge volumes of melt water flowed from the ice sheet's interior to reach the ice sheet's margin. If so, the prairie region erosional escarpments can be used to identify where some of those ice-walled and bedrock-floored canyons once existed.

The Missouri Escarpment is the longest remnant of one of those ice-walled and bedrock-floored canyon walls and extends approximately 1000 kilometers from east central Alberta in a southeast direction across southern Saskatchewan to central North Dakota where it turns in a south direction to reach south central South Dakota. That long 100-to-200-meter high escarpment is what remains of the southwest and west wall of what was a large ice-walled and bedrock-floored canyon, named as the Midcontinent Trench. Last Mountain, the Moose Mountains, and the Turtle Mountains are discontinuous remnants of that canyon's northeast wall and South Dakota's Prairie Coteau west-facing escarpment is an east wall remnant. The Midcontinent Trench ice-walled and bedrock-floored canyon was carved by a large supra-glacial river (the Midcontinent River), which flowed near and roughly parallel to the large ice sheet's southwest and west margin and which emerged from its ice-walled canyon's mouth near where the James River now joins the Missouri River (see Clausen, 2018a). Possible reasons for the supra-glacial Midcontinent River route include ice-sheet related crustal warping raised the decaying ice sheet's southwest margin and/or much greater snowfall near ice sheet margins than in the ice sheet interior meant ice sheet margin areas were higher than ice sheet interior areas.

Other glaciated prairie region erosional escarpments can be interpreted in similar ways. For example, the north-to south oriented Manitoba Escarpment, north-to-south oriented Pembina Escarpment, and the northeast-facing Prairie Coteau escarpment can also be considered to be remnants of another ice-walled and bedrock-floored canyon's west and southwest wall. A south- and southeast-oriented melt water river carved that second ice-walled and bedrock-floored canyon as a huge river delivered immense quantities of melt water to what is today the Mississippi River valley. This second south- and southeast-oriented ice-walled and bedrock-floored canyon (named as the Agassiz Trench) merged with the Midcontinent Trench in southeast North Dakota where a large gap between the Pembina Escarpment southern end and the escarpment bounded Prairie Coteau northern end exists today. Today the low gradient Red River flows in a north direction across Glacial Lake Agassiz sediments, which cover much of the Agassiz Trench floor. Glacial Lake Agassiz has been extensively studied and most workers consider a pre-glacial and low gradient north-oriented Red River was responsible for the eroding the Pembina Escarpment in addition to being a major Bell River drainage system tributary (e.g. Teller and Bluemle, 1983). However, such an interpretation assumes continental ice sheets did not deeply erode the region and the Red River's very low gradient to be a pre-glacial artifact. (The new glacial history paradigm considers Glacial Lake Agassiz, like most other prairie region glacial lakes, to have been formed when the second and thinner ice sheet decayed in a manner not significantly different from what much of the published literature describes.)

\subsection{How First Ice Sheet Melt Water Floods Reversed Direction to Flow Across the Ice Sheet Floor}

Today the James and Sheyenne Rivers originate on the Missouri Escarpment slope and flow from central North Dakota along the Midcontinent Trench alignment roughly adjacent and parallel to each other before the Sheyenne River makes a U-turn in southeast North Dakota to join the low gradient north-oriented Red River, while the James River flows in a south direction to join the Missouri River. The Sheyenne River U-turn indicates the low-gradient north-oriented Red River captured a south-oriented river. Brophy and Bluemle (1983) interpret this capture to have occurred in pre-glacial time and that Late Wisconsin ice subsequently filled the Red River valley and forced the Sheyenne River to flow in a south direction. According to Brophy and Bluemle the Sheyenne River returned to its pre-glacial route when the Late Wisconsin ice melted. However, if a large ice sheet created and occupied a deep "hole" the region was deeply eroded and all evidence of the region's pre-glacial drainage was destroyed, meaning an alternate Sheyenne River U-turn explanation is needed. The gap between the Pembina Escarpment's southern end and the Prairie Coteau's northern end suggests the ice-walled and bedrock-floored Midcontinent and Agassiz Trenches once intersected. The intersection first occurred when immense south-oriented melt water rivers flowed in both trenches. However, the Sheyenne River U-turn suggests an Agassiz Trench flow reversal captured the large south-oriented Midcontinent River and diverted it in a north direction and that the Agassiz Trench flow reversal also reversed flow in at least the northern half of the James River lowland, which is located between South Dakota's east-facing Missouri Escarpment and west-facing Prairie Coteau escarpment.

Gaps between Midcontinent Trench northeast wall remnants are where south-oriented ice-walled and bedrock floored canyons once joined the Midcontinent Trench. The location of one such ice-walled canyon, herein named the Assiniboine Trench, is defined in Manitoba by the south-oriented Assiniboine River, which now flows in a 
broad south-oriented valley to the west of the Duck Mountain and Riding Mountain uplands before turning in an east direction to flow between Riding Mountain and the Turtle Mountains to reach and join the north-oriented Red River. To the south of the south-oriented Assiniboine River valley segment is a north-oriented Souris River segment, which is located to the west of the Turtle Mountains. The Souris River begins as a northwest-oriented river in Saskatchewan and makes a U-turn to then flow in a southeast direction near the Missouri Escarpment base into northcentral North Dakota where it makes another U-turn to flow in a northwest and north direction into Manitoba to join the east-oriented Assiniboine River. The development of an ice-walled canyon along the east-oriented Assiniboine River route between Riding Mountain and the Turtle Mountains not only captured south-oriented flow moving in the Assiniboine Trench northern section (now defined by the south-oriented Assiniboine River valley), but also reversed flow in the Assiniboine Trench's southern section to create the north-oriented Souris River route (west of the Turtle Mountains), which in turn captured the southeast-oriented Midcontinent River and diverted the water in a north and then east direction to join north-oriented water in the newly reversed Agassiz Trench.

Other erosional escarpments and glaciated prairie region river routes suggest the southeast- oriented Midcontinent River was again captured and diverted in Saskatchewan by an ice-walled and bedrock-floored canyon roughly paralleling today's east-oriented Qu'Appelle River. The Qu'Appelle River begins today as a southeast-oriented river to the southeast of a South Saskatchewan River northwest-oriented segment and then turns to flow in an easterly direction to reach the east-oriented Assiniboine River. Klassen, (1972) suggests the "Qu'Appelle and Assiniboine valleys formed as spillways and meltwater channels, mostly within partly re-excavated ancestral valleys...." While those "ancestral valleys" are often considered pre-glacial in origin they could also identify where Midcontinent River water once flowed in an east direction. The northwest-oriented South Saskatchewan River segment is aligned with the southeast-oriented Qu'Appelle River headwaters and also with the northwest-oriented Moose Jaw River (flowing to the Qu'Appelle River) and with northwest-oriented Souris River headwaters, which make a U-turn to flow along the Missouri Escarpment base in a southeast direction to reach northcentral North Dakota where the Souris River makes a second U-turn and flows back into Canada. These river orientations suggest a Qu'Appelle River ice-walled canyon not only captured the southeast-oriented Midcontinent River, but also reversed flow on the northwest end of the beheaded Midcontinent River segment to the create the northwest-oriented Moose Jaw River and the northwest-oriented Souris River headwaters. Kehew and Clayton (1983) relate some of these events to catastrophic failure of Glacial Lake Regina, which the new glacial history paradigm associates with the second and thinner ice sheet.

Reversal of flow in what had been a southwest-oriented Midcontinent Trench tributary ice-walled canyon probably diverted the southeast-oriented Midcontinent River in a northeast direction along the northeast-oriented South Saskatchewan segment downstream and to the north of that river's northwest-oriented segment. The reversal of flow in such a southwest-oriented Midcontinent River tributary ice-walled and bedrock-floored canyon occurred when ice sheet decay opened up new north-oriented routes and captured flow on the beheaded Midcontinent River's northwest end to create the northwest-oriented South Saskatchewan River segment. Today's South Saskatchewan River roughly follows buried valleys which are often considered to be Bell River drainage system components (see maps in Fenton et al, 1994 and in Cummings et al, 2012). However, there is no geologic reason why on the Saskatchewan plains a northeast-oriented pre-glacial river would make a 50-kilometer jog to flow in a northwest direction before turning in a northeast direction again. To the northwest of the South Saskatchewan River's turn (from a northwest direction to a northeast direction) the North Saskatchewan River, which after flowing for more than 100 kilometers in a southeast direction along the Midcontinent Trench alignment, makes a U-turn to flow in a northeast direction suggesting a reversal of flow in still another southwest-oriented Midcontinent Trench tributary ice-walled canyon diverted the southeast-oriented Midcontinent River to the northeast. Between southeast North Dakota's Sheyenne River U-turn and the North Saskatchewan River elbow of capture the Midcontinent River was captured and diverted in a north direction at least five different times.

\subsection{How the Decaying First Ice Sheet Created the Bell River Drainage System}

After turning to flow away from the Midcontinent Trench alignment (along the Missouri Escarpment base) the South and North Saskatchewan Rivers today both flow in northeast directions to join and form the Saskatchewan River, which then joins with the north-oriented Red River and other regional drainages to form the north-oriented Nelson River and to ultimately reach Hudson Bay. These and many other modern-day glaciated prairie region rivers roughly follow routes of buried valleys associated with what many investigators consider to have been pre-glacial Bell River drainage system components. The pre-glacial Bell River drainage system as usually described also included the north-oriented Missouri River headwaters (to the west of figure 1) and north- 
and northeast-oriented Missouri River tributaries such as the Yellowstone River, the Little Missouri River, and the Cheyenne River (seen in figure 1), all of which originate to the south and west of recognized continental ice sheet margins. Partially buried valleys can be traced across the Missouri Coteau and the Missouri Escarpment and are often interpreted to be the pre-glacial routes these rivers used as they headed in a north direction and into and across the recognized glaciated prairie region. If these valleys are not pre-glacial in origin as most publications claim then how did they form?

In South Dakota a large and partially buried valley links the Cheyenne River with the James River lowland and is often described as the route the pre-glacial Cheyenne River used to reach a pre-glacial north-oriented Red River. Further north in central North Dakota another partially buried valley extends from the Missouri River valley across the Missouri Coteau and Missouri Escarpment to where both the James and Sheyenne Rivers originate. In northwest North Dakota the north-northeast oriented Yellowstone River valley and a short downstream north-northeast oriented Missouri River valley segment once continued in a north-oriented partially buried valley that extends across the Missouri Coteau and Missouri Escarpment and which is frequently considered to be a pre-glacial Yellowstone River route. Further to the northwest a partially buried valley extends from the Montana northeast corner across the Missouri Coteau and Missouri Escarpment into the North Dakota northwest corner and is commonly considered to be a pre-glacial Missouri River valley. Most published literature considers these valleys pre-glacial in origin, but almost never addresses how the pre-glacial drainage systems originated or how pre-glacial valleys, which are eroded in the easily eroded bedrock, survived multiple glaciations.

Important to understanding how the new glacial history paradigm explains these partially buried valleys is that if at least one large continental ice sheet created and occupied a deep "hole," the elevation of that ice sheet's floor was significantly lower than the surrounding ice-marginal regions. As a result, the supra-glacial Midcontinent River, which initially flowed on the ice sheet surface at elevations much greater than the surrounding ice-marginal regions, in time was able to slice an ice-walled and ice-floored and subsequently bedrock-floored canyon into the decaying ice sheet's surface with a floor elevation much lower than in the adjacent ice-marginal regions. This elevation difference meant ice-marginal melt water floods that flowed to the southwest of what became the melting ice sheet's detached southwest margin moved at elevations much higher than the Midcontinent Trench floor. As the ice sheet's detached southwest margin decayed water from those ice-marginal floods spilled across ice sheet margin low points to reach the much deeper Midcontinent Trench floor. The result was valleys eroded headward from the Midcontinent Trench floor across the ice sheet's detached southwest margin and into and across the ice-marginal areas to capture the massive southeast-oriented ice-marginal melt water floods. This process began in the southeast and proceeded to the northwest.

North- and northeast-oriented Missouri River tributary drainage systems evolved as north- and northeast-oriented valleys eroded headward from the Midcontinent Trench floor across the decaying ice sheet's detached southwest margin and into higher elevation ice-marginal regions. These valleys in sequence captured the immense southeast-oriented ice-marginal melt water floods and diverted the water to the Midcontinent River. At first the Midcontinent River flowed in its ice-walled and bedrock-floored canyon in a south direction to what is now southcentral South Dakota where it emerged from its canyon and helped to erode the large downstream Missouri River valley (see Clausen 2018a). Also as described the Midcontinent River was repeatedly captured and diverted to flow in north and northeast directions as ice sheet decay opened up new and much shorter north-oriented routes to reach sea level. What the geological literature describes as the pre-glacial Bell River drainage network was formed as massive melt water floods were captured and diverted from the Gulf of Mexico to flow across the decaying ice sheet's floor and to reach the North Atlantic Ocean. The diversion of melt water floods from south to north changed oceanic circulation patterns which in turn changed climatic conditions responsible for the first ice sheet's decay and set the stage so a second and much thinner ice sheet could form. In other words, the Bell River drainage system originated not in pre-glacial time, but late during a large North American ice sheet's decay process.

\subsection{A Second and Much Thinner Ice Sheet Containing First Ice Sheet Remnants}

By the time the north-oriented Bell River drainage system was fully developed intersecting ice-walled and bedrock-floored canyons had subdivided the decaying first ice sheet (the ice sheet which had created and occupied a deep "hole") into smaller detached and semi-detached ice sheet masses. One detached ice sheet mass was the former ice sheet's detached southwest margin, which became narrower as southeast-oriented ice marginal floodwaters ate into its southwest and west margin (accounting for coarse-grained glacial erratic material found to the south and west of the Missouri River today) and leaving a much thinner detached ice sheet remnant where the stagnation moraine covered Missouri Coteau now exists. At least some of the other detached 
ice sheet remnants were located where stagnation moraines now cover escarpment bounded uplands such as the Prairie Coteau, Turtle Mountains, Moose Mountain, Last Mountain, Riding Mountain, and Duck Mountain. These locations are near the decaying ice sheet's margin where the ice sheet contained large quantities of glacially transported debris. As the detached and semi-detached ice sheet remnants melted that debris accumulated on the ice surface so as to insulate the underlying ice, which in turn caused those detached and semi-detached ice sheet masses to slowly melt and to leave stagnation moraines as seen today.

As the large ice sheet was being chopped up into many detached and semi-detached ice sheet remnants meltwater rivers flowed between the detached and semi-detached ice sheet remnants first in south directions and then in north directions. These meltwater rivers removed much of the finer-grained glacially transported material from their beds and also captured significant drainage areas to the south and west of the decaying ice sheet's margin. As long as large volumes of melt water flowed in south directions to the Gulf of Mexico oceanic circulation patterns created climate conditions conducive to rapid ice sheet decay. When melt water floods were diverted to the North Atlantic Ocean oceanic circulation patterns changed and ended climatic conditions responsible for rapid ice sheet melting. The ensuing much colder climatic conditions caused north-oriented water to freeze at first in the north and to form ice dams causing the large volumes of incoming north-oriented water to pond on the former ice sheet floor between the detached and semi-detached ice sheet remnants. Subsequent freezing of the ponded water (from the top down) created a new and much thinner ice sheet consisting of stagnant debris rich former ice sheet remnants surrounded by areas of cleaner and much more mobile wet-based ice.

Evidence for the mobile wet-based ice is particularly evident in northcentral North Dakota just to the northeast of the Missouri Escarpment and to the south of figure 2 where ice-thrust blocks and elongate narrow drumlins have been described and mapped (e.g. Bluemle and Clayton, 1984, and Clayton, 1980), although ice-thrust blocks have been reported in many other regions (Aber et al, 1989) and even in some stagnation moraine areas. The northcentral North Dakota ice thrust features suggest mobile wet-based ice lobes lifted blocks of frozen bedrock to release trapped subglacial water (probably under high pressure). Elongate and narrow drumlins described by Moran et al (1980) and Bluemle et al (1993) can be associated with some of the northcentral North Dakota ice-thrust block masses and suggest significant ice movements. Such movement is consistent with mobile wet-based ice lobes and is quite different from the nearby stagnation moraine areas where debris covered stagnant ice masses appear to have slowly melted. The ice thrust blocks and elongate narrow drumlins are what would be expected if north-flowing water was ponded in spaces between detached and semi-detached ice sheet remnants and then froze from the top down to form a second and much thinner ice sheet. The present-day Missouri River route was established along this second and much thinner ice sheet's southwest and west margin and the second ice sheet also deposited glacial debris in blocked Bell River drainage system valleys and probably melted in ways that at least some of the published literature describes.

\section{Discussion and Conclusion}

The new glacial history paradigm explains how a continental ice sheet created glaciated prairie region erosional escarpments and the north-oriented Bell River drainage system valleys. The erosional escarpments are what now remain of ice-walled and bedrock-floored canyons that supraglacial melt water rivers sliced into the decaying ice sheet's surface. The Bell River drainage system, including valleys now partially filled with glacially deposited sediments, was formed when the decaying ice sheet's melt water floods were captured and diverted in north directions to flow between detached and semi-detached ice sheet remnants across the decaying ice sheet's floor to reach the North Atlantic Ocean. Diversion of melt water floods from the Gulf of Mexico to the North Atlantic Ocean triggered climatic changes that created a second and much thinner ice sheet as water in the newly formed north-oriented drainage routes became dammed and ponded and then froze between detached and semi-detached ice sheet remnants. The second and much thinner ice sheet explains glacially deposited debris now partially filling abandoned north-oriented valley segments and also explains mobile wet-based ice glacial features now found in lowland regions between the escarpment-bounded upland regions. Glacially transported debris contained in the detached and semi-detached first ice sheet remnants explains why stagnant moraines now cover escarpment-bounded upland regions.

According to Kuhn (1970) paradigms are sets of ideas and rules governing how scientific disciplines conduct their research. Kuhn states paradigms by themselves are neither correct nor incorrect and must ultimately be judged by their ability to open up new research opportunities and to explain previously unexplained or poorly explained evidence. The new glacial history paradigm as described here successfully explains many glaciated prairie region glacial and landform features and for that reason alone deserves further consideration. In addition, the new paradigm does not defy common sense logic by requiring landform features carved in easily eroded 
bedrock to have survived continental ice sheet erosion. However, as Kuhn notes resistance to new paradigms is natural and critics can validly point out this finite paper did not address all glaciated prairie region landform features. The new glacial history paradigm will need to be tested over and over again to demonstrate its ability to explain many other glaciated prairie region landform features and also to explain landform features in other geographic regions which were impacted when the new paradigm's large North American continental ice sheet created a deep "hole" developed and also as that large ice sheet melted.

\section{References}

Aber, J. S., Croot, D. G., \& Fenton, M. M. (1989). Glaciotectonic landforms and structures. Glaciology and Geology Series. Kluwer Academic Publishers, Dordrecht, 200p. https://doi.org/10.1007/978-94-015-6841-8

Bluemle, J. P., Lord, M. L., \& Hunke, N. T. (1993). Exceptionally long, narrow drumlins formed in subglacial cavities. North Dakota. Boreas, 22(1), 15-24. https://doi.org/10.1111/j.1502-3885.1993.tb00160.x

Bluemle, J. P. (1972). Pleistocene drainage development in North Dakota. Geological Society of America Bulletin, 83, 2189-2194. https://doi.org/10.1130/0016-7606(1972)83[2189:PDDIND]2.0.CO;2

Bluemle, J. P. (1991). The Face of North Dakota: Revised Edition. North Dakota Geological Survey Educational Series, 21, 177.

Bluemle, J. P. (1993). Exceptionally long, narrow drumlins formed in subglacial cavities, North Dakota. Boreas, 22(1), 15-24. https://doi.org/10.1111/j.1502-3885.1993.tb00160.x

Bluemle, J. P., \& Clayton, L. (1984). Large-scale glacial thrusting and related processes in North Dakota. Boreas, 13(3), 279-299. https://doi.org/10.1111/j.1502-3885.1984.tb01124.x

Brophy, J. A., \& Bluemle, J. P. (1983). The Sheyenne River: its geological history and effects on Lake Agassiz. In Teller, J. T., \& Clayton, L. (Eds.), Glacial Lake Agassiz. Geological Association of Canada Special Paper, 26, 7-20.

Clausen, E. (2017a). Using map interpretation techniques for relative dating to determine a western North Dakota and South Dakota drainage basin formation sequence, Missouri River drainage basin, USA. Journal of Geography and Geology, 9(4), 1-18. https://doi.org/10.5539/jgg.v9n4p1

Clausen, E. (2017b). Origin of mountain passes across Continental Divide segments surrounding the southwest Montana Big Hole and Beaverhead River drainage basins, USA. Open Journal of Geology, 7, 1362-1385. https://doi.org/10.4236/ojg.2017.79091

Clausen, E. (2018a). Interpreting topographic map evidence related to northeast Nebraska barbed tributaries and drainage routes, USA. Journal of Geography and Geology, 10(2), 66-79. https://doi.org/10.5539/jgg.v10n2p66

Clausen, E. (2018b). Deep erosion by continental ice sheets: a northern Missouri River drainage basin perspective: North America. Current Research in Geoscience, 8, 27-38. https://doi:10.3844/ajgsp.2018.27.38

Clayton, L. (1980). Geologic map of North Dakota. North Dakota Geological Survey.

Clayton, L., \& Freers, T. (1967). Glacial geology of the Missouri Coteau and adjacent areas. North Dakota Geological Survey Miscellaneous Series, 30, 226.

Colton, R. B., Lemke, R. W., \& Lindvall, R. M. (1963). Preliminary Geologic Map of North Dakota. North Dakota Geological Survey map prepared by the United States Department of the Interior.

Cummings, D. L., Russell, H. A. J., \& Sharpe, D. R. (2012). Buried-valley aquifers in the Canadian Prairies: geology, hydrogeology, and origin. Canadian Journal of Earth Sciences, 49(9), 987-1004. https://doi.org/10.1139/e2012-041

Dyke, A. S. (2004). An outline of North American deglaciation with emphasis on central and northern Canada. In: Ehlers, J., Gibbard, P.I. (Eds.), Quaternary Glaciations-Extent and Chronology, Part 2 North America. Developments in Quaternary Sciences, 2(b), 373-424. https://doi.org/10.1016/S1571-0866(04)80209-4

Fenneman, N. M. (1931). Physiography of Western United States. McGraw-Hill Book Company, New York, 534.

Fenton, M. M., Schreiner, B. T., Nielsen, E., \& Paskowicz, J. G. (1994). Quaternary geology of the Western Plains, chapter 26. In Mosop, G. D., \& Shetsen (Eds.), Geological Atlas of the Western Canada sedimentary basin (pp. 413-420). Canadian Society of Petroleum Geologists and Alberta Research Council, Special 
Report 4.

Flint, R. F. (1955). Pleistocene geology of eastern South Dakota. United States Geological Survey Professional Paper, 262, 173. https://doi.org/10.3133/pp262

Jackson, L. (2018). The Paleo-Bell River: North America's vanished Amazon. Earth, 63(7-8), 74-81.

Kehew, A. E., \& Clayton, L. (1983). Late Wisconsin floods and development of the Souris-Pembina spillway system in Saskatchewan, North Dakota, and Manitoba. In Teller, J. T., \& Clayton, L. (Eds.), Glacial Lake Agassiz (pp. 187-209). Geological Association of Canada Special Paper, 26.

Klassen, R. W. (1972). Wisconsin events and the Assiniboine and Qu'Appelle valleys of Manitoba and Saskatchewan. Canadian Journal of Earth Sciences, 9(5), 544-560. https://doi.org/10.1139/e72-044

Kuhn, T. (1970). The structure of scientific revolutions: second edition, enlarged. The University of Chicago, 210.

Leckie, D. A. (2006). Tertiary fluvial gravels and evolution of the Western Canadian Prairie landscape. Sedimentary Geology, 190(1-4), 139-158. https://doi.org/10.1016/j.sedgeo.2006.05.019

Lemke, R. W. (1960). Geology of the Souris River area North Dakota. United States Geological Survey Professional Paper, 325, 138. https://doi.org/10.3133/pp325

Lemke, R. W., Laird, W. M., Tipton, M. J., \& Lindvall, R. M. (1965). Quaternary geology of Northern Great Plains. In Wright, H. E., \& Frey, D. G. (Eds.), The Quaternary of the United States. 15-28.

Moran, S. R., Clayton, L., Hooke, R. B., Fenton, M. M., \& Andriashek, L. D. (1979). Glacier-bed landforms of the prairie region of North America. Journal of Glaciology, 25(93), 457-476. https://doi.org/10.1017/S0022143000015306

Paterson, W. S. B. (1972). Laurentide ice sheet: estimated volumes during the Late Wisconsin. Reviews of Geophysics and Space Physics, 10(4), 885-917. https://doi.org/10.1029/RG010i004p00885

Sears, J. W. (2013). Late Oligocene-early Miocene Grand Canyon: a Canadian connection? GSA Today, 23, 4-10. https://doi.org/10.1130/GSATG178A.1

Sugden, D. E. (1976). A case against deep erosion of shields by continental ice sheets. Geology, 4, 580-582. https://doi.org/10.1130/0091-7613(1976)4<580:ACADEO >2.0.CO;2

Teller, J. T., \& Bluemle, J. P. (1983). Geological setting of the Lake Agassiz region. In Teller, J. T., \& Clayton, L. (Eds.), Glacial Lake Agassiz Geological Association of Canada Special Paper (Vol. 26, pp. 7-20).

Thornbury, W. D. (1965). Regional Geomorphology of the United States. John Wiley and Sons, New York, 607p.

Townsend, R. C., \& Jenke, A. L. (1951). The problem of the Max moraine in North Dakota and Canada. American Journal of Science, 249, 842-858. https://doi.org/10.2475/ajs.249.11.842

White, W. A. (1972). Deep erosion by continental ice sheets. Geological Society of America Bulletin, 83(4), 1037-1056. https://doi.org/10.1130/0016-7606(1972)83[1037:DEBCIS]2.0.CO;2

\section{Copyrights}

Copyright for this article is retained by the author(s), with first publication rights granted to the journal.

This is an open-access article distributed under the terms and conditions of the Creative Commons Attribution license (http://creativecommons.org/licenses/by/4.0/). 